\title{
Universiteit
}

Leiden

The Netherlands

\section{Scythian elements in Old Iranian}

Lubotsky, A.M.; Sims-Williams N.

\section{Citation}

Lubotsky, A. M. (2002). Scythian elements in Old Iranian. In Indo-Iranian Languages and Peoples (Proceedings of the British Academy 116) (pp. 189-202). Oxford: Oxford University Press. Retrieved from https://hdl.handle.net/1887/16379

\author{
Version: $\quad$ Not Applicable (or Unknown) \\ License: $\quad$ Leiden University Non-exclusive license \\ Downloaded $\quad$ https://hdl.handle.net/1887/16379 \\ from:
}

Note: To cite this publication please use the final published version (if applicable). 


\section{Scythian elements in Old Iranian}

\section{ALEXANDER LUBOTSKY}

1.1. DURING THE FIRST MILLENNIUM B.C., the Central Asian steppes were inhabited by a group of tribes, called Sakas by the Persians and Scythians by the Greek. They controlled an enormous territory from the banks of the Danube across the Pontic steppes to Central Asia. We do not know whether these peoples spoke the same language, but they presumably were culturally homogeneous, as follows from the archaeological evidence: all over the Eurasian steppes we find in the first millennium the 'Scythian' short sword, the trilobate arrowhead and the so-called 'Animal Style' decoration.

From Classical and Mesopotamian sources we learn that sometime during the late eighth and seventh centuries B.C., the Scythians invaded Media and the Near East and dominated the lands of the Urartians, the Mannaeans and the Medes for several decennia. This period led to inevitable amalgamation. In the seventh century B.C., Urartian soldiers start wearing a Scythian bashlyq, very different from the helmet worn by the Urartians in the preceding centuries. Various peoples of the Iranian plateau and beyond wear Scythian clothing and weaponry at least by the end of the sixth century B.C., as can be seen on the Persepolis reliefs. Scythian influence can further be deduced from the story told by Herodotus $(I, 73)$ that the Median king Cyaxares sent young boys to the Scythians to learn their language and the art of archery.

On the basis of extensive historical and archaeological evidence, my colleague Willem Vogelsang convincingly argued in his 1992 book that the Scythians must have played an essential role in the rise and organisation of the Achaemenid empire. It therefore seems legitimate to ask whether we can find Scythian loanwords in the Old Iranian languages, namely Avestan and Old Persian. It must be borne in mind that since all three languages are closely related, it is not simple to prove borrowing. As is well known, Old Persian vocabulary contains many words which must be of Iranian but non-Persian origin. These words are usually attributed to Median, but it is in principle equally possible that they are borrowed from any other Iranian language, including Scythian. Only when we find phonological features which are characteristic of Scythian can we be confident that we are indeed dealing with a Scythian loanword. 
Unfortunately, we know next to nothing about the Scythian of that period-we have only a couple of personal and tribal names in Greek and Persian sources at our disposal-and cannot even determine with any degree of certainty whether it was a single language, ${ }^{1}$ Our information about Sarmatian and Alanic, which represent the 'Middle Iranian' stage of Scythian, is also practically restricted to personal names, whose etymological analysis is often uncertain. We only get onto firm ground when we consider the historical development of Ossetic, the modern representative of one of the Scythian dialects. ${ }^{2}$ In a situation like this, it seems necessary to start from Ossetic and then to move backwards. In other words, we must select Ossetic sound changes which belong to the oldest layer, check whether these are also reflected in Sarmatian and Alanic names, and then hypothesise that they already took place in Scythian. Needless to say, the last step must necessarily remain uncertain. Nevertheless, if we find an apparently Iranian word in Avestan or Old Persian that does not agree with the sound laws of these languages, and if the specific sound change concerned is typical of Ossetic and Sarmatian-Alanic, we may seriously consider the possibility of a Scythian origin.

1.2. There are two major isoglosses which separate Ossetic from the other Iranian languages, namely Iranian ${ }^{*} p>$ Oss. $f$ and Iranian $* t i>$ Oss. $c{ }^{3}$ Both developments are already found in Sarmatian names in Greek inscriptions from Southern Russia (1st cent. B.C. to 3rd cent. A.D.), at least if our analysis of the names is correct.

The problem with the sound change $*_{p}>f$ is that the inscriptions write both $\pi$

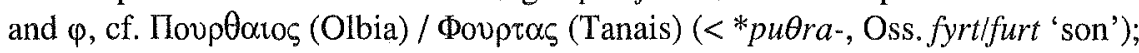

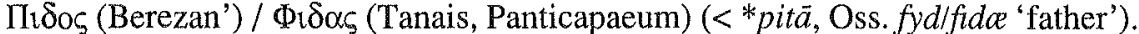
Abaev (1949: 212f.; 1979: 332) interpreted the $\pi / \varphi$ alternation diachronically, but, as indicated by Bielmeier (1989: 240), the different reflexes may belong to different dialects: forms with $\pi$ are attested in the West (Olbia), whereas forms with $\varphi$ are found in the East. We may therefore assume that the sound change ${ }^{*} p>f$ was typical of East Scythian dialects. ${ }^{4}$

Assibilation $* t i>t^{s} i$ (with voicing to $* d^{z} i$ in intervocalic position) is found in two Sarmatian names from Olbia: 'Iv $\sigma \alpha \zeta_{2} \alpha \gamma \circ \varsigma$, which is usually interpreted as Oss, *insazceg 'Vicentius' (Abaev, IESOJ IV, 277; cf. Oss. ysscez/insaej 'twenty'

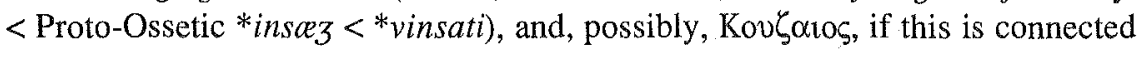

${ }^{1}$ Henceforth I shall use 'Scythian' as a cover term for the Old Iranian stage (i.e. ca. tenth to third centuries B.C.) of the North Iranian dialects.

2 An important argument in favour of the view that Ossetic is indeed 'Neo-Scythian' is furnished by the name of the Scythian rebel Skunxa, who was captured by Darius (DB 5,27). As was indicated by Frejman (1948: 239f), this name is likely to correspond to Oss. (Dig) ask'wonxun 'to be distinguished'. ${ }^{3}$ The latter sound change is also found in Choresmian, but as a part of a more general assibilation

process.

${ }^{4}$ It is of course also possible that there were different traditions in the representation of a Sarmatian sound for which there was no equivalent in the Greek alphabet, e.g. [ $\varphi]$ (a bilabial spirant). with Oss. kuz 'puppy' (thus Abaev 1949: 171, who compares the Ossetic personal names $K u z a$ and $K u z a g$ ). Here, too, we may hypothesise that the assibilation may already have occurred in Scythian or in some of its dialects.

\section{Avestan $x^{v}$ aronah / Iranian * farnaht-}

2.1. I have recently discussed the etymology and concept of Avestan $x^{v}$ arznahand its Iranian cognates (cf. Lubotsky 1998), so that I shall only indicate the main lines here.

The best semantic analysis of $x^{v}$ aranah - was given by Sir Harold Bailey in his Ratanbai Katrak lectures (1943: 1ff.). On the basis of a meticulous analysis of Avestan and Pahlavi passages, Bailey arrives at the following rendering of $x$ "aranah- (p. 29): "from the primary meaning "the thing obtained or desired" by way of "good things" and "riches" to the "good fortune" assured by riches to the possessor of hvarnah, and thence to "Fortune", a divine (mënōkik) hypostasis, and a force bestowing "good fortune" including all success and victory". In anticipation of the discussion later on, I shall tentatively gloss Av. $x^{v} a r a n a h$ - by 'prosperity'.

Let us look at the major constructions involving Av. $x^{v}$ aronah-. The most frequent formula with $x^{v} a r a n a h$ is the octosyllabic line ahe (manalänham) raiia $x^{v}$ arananhaca 'on account of his (my/their) wealth and prosperity', which occurs hundreds of times in the Yašts. A typical example is Yt. 3,18 (et passim):

ahe raiia $x^{2}$ aronanhaca tom yazäi surunuuata yasna

'On account of his wealth and prosperity,

I will worship him with audible veneration.'

'Wealth and prosperity' appear together in other formulae, too, cf. raëšca $x^{v}$ aranasca, raiiamca $x^{v}$ aronanhamca, raëuuant- $x^{v}$ aranaj ${ }^{v} h a n t-$. They are attributes of a god, who can bestow them on a devotee. In Yt. 10,108, for instance, Mithra asks:

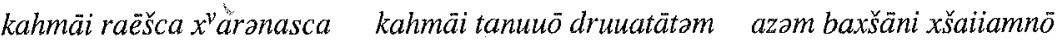
'On whom shall I, who possess them, bestow riches and prosperity,

on whom health of the body?'

Another frequent juxtaposition is formed by $x^{v}$ aranah- and sauuah - 'power',

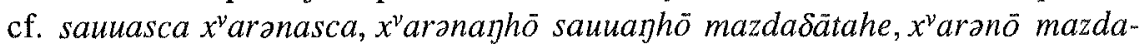

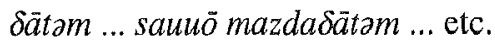

Our knowledge about $x^{v}$ aronah-comes primarily from the Yašts. In Yt. 19, two types of $x^{v}$ aranah- are distinguished: kauuaem $x^{v} a r a n \bar{o}^{-}$'the prosperity of the Kavi-dynasty' and ax aratam $x^{v}$ arano. The kauuaẽm $x^{v}$ arano belongs to the gods, who by its power create and preserve the world. It also accompanies the ancient kings and heroes and gives them extraordinary powers. The ax aratam $x^{v}$ aranō, on the other hand, is described as an object of desire for divinities and heroes, 
who constantly struggle for it. Ahura Mazdā even prescribes that every mortal should fight for the axvaratam $x^{v}$ aranō. The meaning and etymology of the adjective $a x^{v}$ aratam are disputed, but it must mean something like 'undistributed'.

In Yt. 18, the Aryan $x^{v}$ aranah (airiianam $x^{v}$ aranō) is honoured. It was created by Ahura Mazdā, is full of milk and pastures and overcomes the daēvas and the non-Aryan countries.

2.2. The major problem we encounter when dealing with the etymology of this word is its initial. Whereas Av. $x^{v}$ arznah-, Pahl. xwarrah and Pers. xurra point to initial $* x^{\nu_{-}}$, the other languages show initial * $f$-, cf. OP ${ }^{\circ}$ farnah- in the PN $V i^{n} d a$ farnah-, Man. MP and Parthian prh, frh /farrah/ 'fortune, glory', Sogd. (Buddh.) prn, (Man.) frn, (Chr.) fn /farn/ 'glory, high rank', Bactrian $\phi \alpha \rho(\rho)_{o}$ on Kushan coins, Khot. phärra- 'splendour, rank (of Buddha)', Pers. farr(a), Oss. farn/farna 'happiness, wealth, well-being'.

For a long time it was held that the initial $f$-is due to a specific Median soundlaw PIr. * $x^{\nu}$ - $>$ Med. $f$-. It was assumed that farnah - was borrowed by Old Persian from Median, and then disseminated all over the Iranian territory in the period of the Achaemenid empire. In 1983, however, Skjærvø convincingly showed that the 'Median' theory is untenable. His conclusions can be summarised as follows:

a. It is impossible to prove that farnah - is an originally Median word and that there was an exclusively Median development $* x^{\nu}->f$.

b. Forms with $f$ - are attested throughout the whole Iranian territory, whereas * $x^{v}$ - is confined to Avestan. Pahl. xwarrah and Pers. xurra can be considered loanwords from Avestan.

c. There is no evidence that farnah-was so important in the Achaemenid empire that this term should have been borrowed by all Iranian dialects of that time and replaced the local variants.

I agree with Skjærvø that the distribution of the forms clearly shows that farnah-must be the original form. The initial $x^{\nu}$ - of Av. $x^{v}$ arzanah-can easily be explained by substitution of $x^{v} a$ - for $f a-$, which is frequently attested in loanwords. For instance, in South Russian dialects, $f$ in loanwords regularly appears as $x^{w}$, cf. $x^{w} a ́ b r$ 'ika 'factory' (Standard Russ. fábrika), $x^{w} a n a ́ r '$ ' lantern' (Standard Russ. fonár', a borrowing from Gr. pavópiov); Middle Welsh Chwefror 'February' is a borrowing of Latin Februārius; in Finnish, we find sohva 'sofa', kirahvi 'giraffe' etc.

Furthermore, there is an important linguistic argument against a Proto-Iranian reconstruction * $h^{v}$ arnah-, which, as far as I know, has never been mentioned in the literature. (For a detailed discussion of the evidence I refer the reader to Lubotsky 1999.) Avestan compounds with second members in ${ }^{\circ} x^{\nu}$ - normally appear with $-s(.) x^{\nu}$-after $i, u, r$, which is a result of the RUKI rule, cf. $h u s x^{v} a f a, 3$ sg. pf.

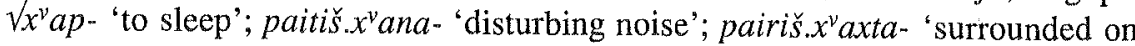
all sides'; paitiš(.) $x^{v}$ arəna- 'jaws'; aißis. $x^{v} a r \partial \theta a$ - 'suitable for consumption'; mainiiuš. $x^{v} a r \partial \theta a$ - 'reared on supernatural food'; pasuš. $x^{v} a r \partial \theta a-\mathrm{n}$. 'food for cattle'. The exceptions are very few: apart from three compound verbs, un-

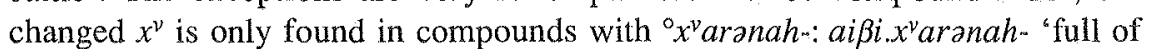
$\mathrm{x}^{\mathrm{v}}$ arənah-'; pouru. $x^{v}$ aronah- 'with much $\mathrm{x}^{\mathrm{v}}$ aronah-'; vindi- $x^{v}$ aronah- 'with found

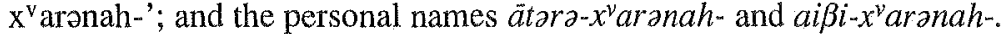

Also in the position after $-\tilde{a}$, the initial $x^{v}$ of ${ }^{\circ} x^{v} a r \partial n a h$ - remains unchanged (ušta. $x^{v}$ aranah-, vïspö.xvaronah-, barö. $x^{v}$ arznah-, haomö. $x^{v}$ aranah-), whereas, for instance, the initial $x^{v}$ of ${ }^{\circ} x^{v}$ arana- 'eating' often appears as $-\eta^{v} h-\left(\stackrel{\circ}{a} \eta^{v} h a r a n a-\right.$ 'dish, bowl', hay' harana- 'cheek').

This state of affairs clearly shows that the initial $x^{y}$ - of Avestan $x^{v}$ aranah-cannot reflect Proto-Iranian *hu- $<$ PIE *su-.

2.3. The insight that *farnah- is the original form opens new perspectives for the etymological analysis. In the following I shall argue that *farnah goes back to PIr. *parnah- and is cognate to Skt. párinas-, which is not only the same morphological formation but has the same range of meanings.

Skt. párïnas- $\mathrm{n}$. is traditionally glossed 'fullness, abundance, prosperity' and derived from the PIE root *pelh $I^{-}$'to fill' (cf. Mayrhofer, EWAia, s.v.). For Skt. párinas- we can reconstruct PIE * pelh -nos-, the expected Iranian reflex of which is * parnah - with regular loss of the laryngeal in inlaut. We shall return to the problem of the Iranian initial $f$-below, but first we have to look at the actual occurrences of Ved. párinas-. This word is attested only in the Rgveda (all other attestations being Rgvedic repetitions or variants). It occurs eleven times as a simplex and twice in the compound góparinas-. Finally, there is one attestation of the adjective or neuter parinasá-.

Among the eleven occurrences of párinas-, we find four times an asyndetic formula rāýá párinasä at the end of the line, three times referring to Indra and once to Agni. A typical example is $8,97,6 \mathrm{a}-\mathrm{d}$ (other passages are 1,129,9a; $4,31,12 b ; 5,10,1 \mathrm{c})$ :

$$
\begin{aligned}
& \text { sá nah sómeșu somapāh _ sutéșu śavasas pate / }
\end{aligned}
$$

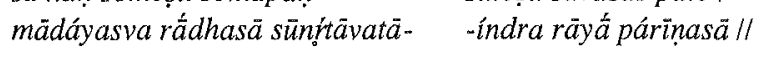

'Get intoxicated with our pressed-out Soma-juices, O Indra, Soma-drinker, Lord of power, with (your) bountiful gifts, with (your) wealth (and) párinas-.'

The formula räyá párīnasā is no doubt identical with the Avestan formula (ahe/mana/änham) raiia $x^{v}$ arananhaca and goes back to Indo-Iranian times. Let us now review the other passages with párings-. At the end of a hymn to the Maruts, 1,166,14, we read:

$$
\begin{aligned}
& \text { yéna dïrghám marutah suusáávāma yușmákena párịnasā turāsah / } \\
& \text { à yát tatánan vrjáne jánảsa ebhír yajñébhis tád abhî́stim aśyām /l }
\end{aligned}
$$

'Your párinas-, O Maruts, through which we shall stay powerful for a long time, $\mathrm{O}$ strong ones, and which (other) people will try to draw into their surrounding, is what I seek to acquire with these sacrifices as a gift.' 
First of all, the passage shows that there is a direct connection between párinas- and power (root $s \bar{u}$-), which is reminiscent of the Avestan pair sauuasca $x^{v}$ aranasca. Furthermore, we may conclude from the passage that párinas- is not simply 'abundance', but also some kind of military superiority or sovereignty The imagery is essentially the same as that of Avestan airiianzm $x^{\nu}$ aronō.

Just like Av. $x^{v}$ aranah-, Vedic párinas- is a quality possessed by the gods (especially Indra and the Maruts), which can be bestowed on the devotees. This also follows from $8,21,7$ :

\section{nútnä id indra te vayám \\ ütí abhüma nahi nú te adrivah I} vidmấ purá párịnasặ /l

'We of the new generation are dependent on your help, Indra. We have known your párinas-, not (only) now but also before, $\mathrm{O}$ master of the pressing stones.'

A more profane aspect of párinas- becomes apparent from 1,133,7a: vanóti hí sunván ksáyam párinasah 'The presser (of Soma) wins indeed a house of párínas-'. The idea that $x^{v}$ aranah- is present in the house of a devoted man follows, for instance, from Y. 60,7: mä yauue imat nmānam $x^{v} \bar{a} \theta$ rauuat $x^{v}$ aronō frazahīt 'May the comfort-bringing $x^{v}$ aranah-never leave this house'.

2.4. We can now return to the question of the initial $f$. of Iranian farnahinstead of the expected $* p$-. Since farnah- is most probably a dialectal Iranian form, it must originate from an Iranian language where * $p$ regularly yields $f$. As indicated above $(\$ 1.2)$, this sound change is only found in Ossetic and Sarmatian and can thus be postulated for Eastern Scythian dialects. The first attestation of the element farnah- in Median onomastics can be dated around 714 B.C. (the reign of Sargon II, 721-705 B.C., cf. Lecoq 1987: 678). At that time, Media was invaded by Scythian tribes and most probably many Median princes and high military officials were of Scythian descent.

We may conclude that Iranian farnah- is of Scythian origin and is cognate with Vedic párinas-, as shown by the Avestan and Vedic formulae. The original meaning of Indo-Iranian *parHnas- was 'sovereignty, control', then 'abundance'. Avestan $x^{v}$ aranah-is a borrowing from Scythian with substitution of $x^{v} a$ - for the initial $f a-.^{5}$

There are two additional arguments for the Scythian origin of this word.

First, 'sovereignty, dominion, control over a territory' seems to be an essential element of Av. $x^{v}$ aranah- and its Iranian cognates (note, for instance, the continual struggle for $a x^{v}$ aratam $x^{v}$ aranō 'the undistributed dominion', described in Yt. 19). Control of a vast territory is especially vital for a nomadic society: it has been calculated that in order to raise 6.7 cows or horses in the Eurasian steppes one needs 1 square $\mathrm{km}$ of pasture (Kuz'mina 1994: 205)

\footnotetext{
${ }^{5}$ The genuine Avestan word related to Scythian farnah- and Skt. párinnas- is Av. *paranah-, preserved
} in the adjective paranaphuntam (Yt. 5,130), meaning something like 'abundant'.
Secondly, if we look at the meaning of *farnah-words in all Middle and Modern Iranian languages, we see that the broadest range of meanings is attested in Ossetic, where farn/farnce is not only an attribute of heroes but also refers to the happiness, peace and prosperity, which can be wished for and achieved in every house. In all other languages, *farnah- is in general only a technical term.

2.5. The Scythian origin of $x^{v}$ aranah- has important chronological implications for dating the Avesta, since this word is already attested in the Gathas ( $x^{v}$ arano, Y 51.18). ${ }^{6}$ When could the speakers of Avestan have borrowed the word $x^{v}$ aranah-from the Scythians? The answer to this question cannot be definitive, since the Scythians must have been in contact with Avestan speakers for a long period of time. (It is traditionally assumed that the Avesta was composed in Eastern Iran, in Marv or Herat, cf. Hoffmann and Narten 1989: 87.) On the other hand, the Scythians became really powerful somewhere around the end of the ninth century B.C., before they came to the Iranian plateau and conquered Media. It is therefore likely that the borrowing of the word $x^{y}$ aronah-, which was an important Scythian concept, took place not before the late ninth or early eighth century. This argument thus furnishes a terminus post quem for the creation of the Old Avestan texts. It is only slightly later than the conventional dating, which, on linguistic grounds, places the Old Avesta somewhere around the tenth century (cf., for instance, Hoffmann and Narten 1989: 88 with references). There are also other points of view, however. For instance, Skjærvø (1994: 201) assumes that Old Avestan texts were composed in the period 1700-1200 B.C., which is much too early if our reasoning concerning $x^{\nu}$ aranah- is correct.

\section{Old Persian forms with $\theta i$ and the month-name $\theta$ äigraci-}

3.1. I have found three Old Persian words containing the sequence $\theta i$ where on etymological grounds we would expect $t i:{ }^{7}$ duvar $\theta i$ - 'portico, colonnade', skau $\theta i-1$

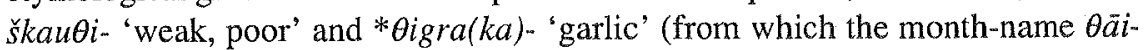
graci-is probably derived, see below). Theoretically, the $-\theta$ - of the former two words can be explained by generalisation from the oblique cases of an original hysterodynamic paradigm with * $\theta i<* t i$, in the same way as $g \bar{a} \theta u$ - "place, throne' must have got its $\theta$ (cf. Av. gãtu-, gen. sg. gätuuö, with generalisation in the other direction). In the case of $* \theta i$ we have the additional complication, however, that

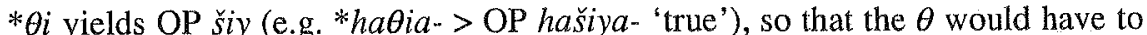
have spread to the strong cases before the development $* \theta i>$ OP $s i y$ took place,

${ }^{6}$ The passage has received various interpretations, but all scholars agree that $x^{v}$ arənō must be a form of $x^{y}$ aranah-

7 Traditionally, OP $x$ šäyatiya- 'king' has also been seen as a non-Persian word because of its ${ }^{\circ} \theta i y a$ (allegedly from PIr, ${ }^{\circ}{ }^{\circ} \theta i a-<* *^{\circ} t i a-$ ). As Hoffmann (1976: 637 n. 26) has convincingly argued, however, OP xšăyatiya- is a vryddhi-formation derived from *xšaya $\theta a$ - 'reign' with the suffix -iya-< * iHo- 
the oblique cases subsequently generalising the $\theta$ on the basis of the strong cases. Although this explanation is not totally impossible, it is not very appealing either, especially since the hysterodynamic inflection is moribund in Indo-Iranian languages and is only attested in a few archaic words, whereas 'portico' and 'weak, poor' do not belong to the basic vocabulary. Therefore, some scholars have seriously considered borrowing from Median. For instance, Mayrhofer (1964: 118 with references) writes about duvar $\theta i \cdots$ : 'das Hinterglied viell. ursprünglich *v(a)rti-, mit - $b$ - aus obliquen - $p y$-Kasus. Die Lautumgebung wäre medisch'. This solution is of course impossible for * $\operatorname{\theta igra}(\mathrm{ka})$-, so that I would rather suggest borrowing from a Scythian dialect with assibilation of $* t i * t^{s} i$ (cf. $\$ 1.2$ ) for all three words. ${ }^{8}$ The $\theta$ of Old Persian may be due to substitution (cf. the

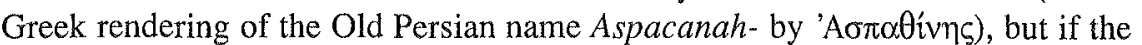
borrowing is sufficiently old-the contacts of the Persians with the Scythians may date back to the 8 th cent. B.C.- Scythian *ts could have been taken over with ${ }^{*} \dot{C}$ or $* s$ (the same as the reflex of PIE $* \hat{k}$ ), which only later merged with $\theta$ in Old Persian. A similar scenario must at any rate be assumed for the name of Egypt, which had an emphatic $s$ in Semitic languages (Akk. mi-sir-a-a, Hebrew misrayim) and which was borrowed by Old Persian in a form like *mu(d)zräya $\rightarrow$ mudrāya (cf. Hoffmann 1958: 3).

Let us now look at the etymologies of these words in more detail.

3.2. duvar $\theta i$ - 'portico, colonnade' is found in the passage XPa 11f, which

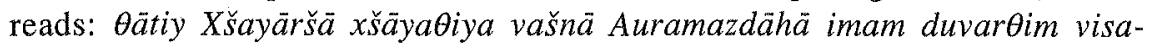
dahyum adam akunavam 'Says Xerxes the king: By the favor of Ahuramazda, this Colonnade of All Lands I built' (tr. Kent 1954: 148). It is beyond any doubt that duvar $\theta i$ - is derived from the word for 'door'. The only moot point is whether $d u v a r \theta i$ - is a derivative with the suffix - $t i$ - or represents a haplologised compound *dvar-v(a)rti-, as already suggested by Bartholomae in his dictionary. The communis opinio opts for the latter derivation, but I see no reason for this: the suffix - $t i$ - is of course rare in denominal formations, but since we find words like Skt. pátti-, OP pasti- 'pedestrian' (for the denominal -ti- see Wackernagel and Debrunner 1954: 639ff.), the analysis of duvar $\theta i$ - as *duvar-ti- seems to me perfectly acceptable.

The word for 'portico' is also attested (with an additional suffix) in MP d'hlyc [dahlizz], Man. MP dhryz [dahrizz], Persian dahliz, and has been borrowed from Middle Persian into Armenian (dahlič) ${ }^{9}$

3.3. The etymological explanation of skau $\theta i-/$ škau $\theta i$ - 'weak, poor' is problematic. The word is always used in the Old Persian inscriptions in opposition to /tunuvant-/ 'powerful, strong' (DNb 8f. $\approx$ XP1 9f., DB 4,65) or to the comparative

\footnotetext{
8 The semantics of these words is typical of borrowed vocabulary.

9 Incidentally, Slav. *dvorbcz 'palace' may also be an Iranian loanword, but this cannot be demon
} strated, since the Slavic word could represent a derivative of * $d v o r z$ 'court' with the suffix *iko-. /tauviyä/ 'the stronger one' (DSe 39f.). The initial $\check{s}$ is only found in the Behistun

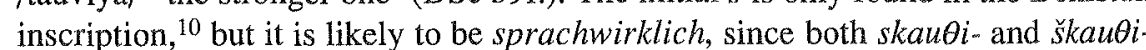
are reflected in Western Middle Iranian, as Man. Parthian 'skwh /iskōh/ and Man. MP ‘škwh /išköh/ (see Schmitt 1990: 47 contra Wüst 1966: 284 n. 1). The initial $s k$-, which can hardly be explained as a regular IE formation, the vacillation between $s k$ - and $\varsigma k$ - and the unclear - $\theta i$ - clearly point to borrowing; therefore quite agree with Kent $(1950: 40,52)$ that skau $\theta i$ - is a loanword. ${ }^{11}$ It need not be borrowed from an Iranian language, of course, but if it is, we can think of the original $* s k(a) u-t i$ - (assuming again that $-\theta i$ - stands for Scythian $-t^{s} i$-), a derivative with the suffix - $t i$ - from the root *sku- 'to tear' (see Mayrhofer, EWAia, s.v. $S K A V-$ ). For the formation and semantics we can even compare Oss. sk'wydzag/ $s k$ 'udzag 'a torn off piece, scrap, shred', also used for a 'torn off, isolated, weak person' (cf. the examples cited in Abaev, IESOJ, s.v.), which is derived from the verb $s k^{\prime w} y n y n / s k$ 'unun 'to tear, exterminate', intransitive $s k^{\prime w} y j y n / s k$ ' ujun 'to be torn, to grow scarce, die out' ${ }^{12}$ The only problem is the full grade in OP skau日ibecause for a $t i$-derivative we would expect zero grade in the root (although full grades are also occasionally found, cf. Wackernagel and Debrunner 1954: 630). Since we are presumably dealing with a loanword here, we can also explain it as as adaptation or mishearing of a foreign word. It is conceivable, for instance, that Scythian $u$ was more open than the Old Persian one and was therefore rendered by $a u$.

A similar root etymology (but of course on the assumption of an inherited word) was already proposed by Herzfeld (1938; 307f), who pointed to Av kutaka - 'small'. This was accepted by Wüst (1966: 284), who added Lithuanian cognates such as skùtas 'shred'. Hoffmann (1957: 62=1976: 414) also took Av. kutaka - and OP skau $\theta i$ - together, but connected them with the Indo-European verbal root *kau- 'to humiliate' (Skt. kava- 'Erniedrigung, Beeinträchtigung, Minderung', Goth. hauns 'humble', etc.). As for the formation of skauti-, Hoffmann took it as a $v r d d h i$ derivative to *sku$\theta a$ - 'Erniedrigung', which seems hard to reconcile with the short diphthong in the OP word (cf., for instance, OP $\theta$ äigraci- in the next section).

${ }^{10}$ For the reading see Schmitt 1990: 46f.

11 Gershevitch (1954: 55) suggested a connection with Sogd. škwr $\delta$ 'difficult' on the assumption that $-r$ - is secondary in Sogdian. In answer to my query about the form, N. Sims-Williams wrote to me $(26$ November 1999): 'Sogd. $\breve{k} k w r \delta$ is written $\breve{s q w r \theta}$ in Chr. Sogd. Final $-r \theta$ can be due to metathesis as in

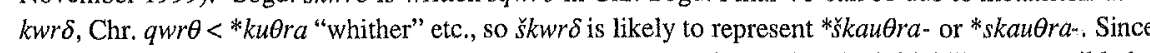
the $-r$ - is constant it cannot be ignored as Gershevitch assumed in 1954 . The initial $r k$ - can possibly be explained from OIran. *sk- (see Gershevitch), but of course OP already has the variant škau $i-$, cf. MP $i$ išōh. I suppose that the OP and Sogd, meanings represent as it were passive and active senses: "subject to oppression/difficulty" vs. "causing oppression/difficulty"', The problem with this etymology is however that the suffix *-tra. never forms adjectives in Indo-Iranian.

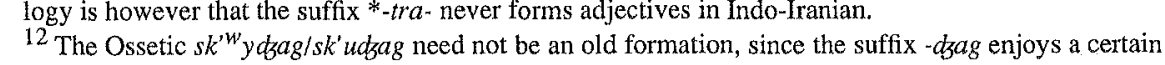
productivity in Ossetic. 
3.4. The Old Persian month-name $\theta$ äigraci- (= Elam. sa-a-kur-ri-zi-iš) is attested in the Behistun inscription (DB 2,46-7) in the gen. sg. Aäigracaiš $<\theta-\mathrm{a}-\mathrm{i}-$ $\mathrm{g}-\mathrm{i}-\mathrm{c}-\mathrm{i}-\mathrm{s}>$. This is the third month of the pre-Zoroastrian calendar (May-June), corresponding to Aram. Sivan, Akk. Simannu. As a result of the studies of Justi, Eilers and Wackernagel, there is now a kind of hesitant consensus on its reading, formation and etymology (cf. Brandenstein and Mayrhofer 1964, Sims-Williams 1991: 178 , etc.).

The first step was taken by Justi (1897), who pointed out that Old Persian $\theta$ äigracaiš is "ein mit Vroddhi gebildetes Beiwort zu "Monat". Justi further considered * $\theta i g r a$ - to be the ancestor of Modern Persian sir 'garlic', with the same sound development as in tïr 'arrow' <*tigri- (Av. tirri-). He analysed * $\theta i g r a c i$ as a compound 'Knoblauch-Sammler', containing the root $c i$ - 'to gather', and explained the name of the month as 'der Monat der Knoblauchsammler'. Justi further stressed the important role of garlic in the ancient world and mentioned the Persian Sirsür 'feast of garlic'.13 As to the etymological connections of the apparent Proto-Iranian *cigra-, Justi mentioned Skt. sigru- 'Moringa pterygosperma (horseradish tree)' (Sü+) ${ }^{14}$ and śaigrava- 'its fruit, ben-oil (pressed from its seeds)'.

Justi's explanation was originally met with enthusiasm (for instance, it was accepted by Horn, GIP, I/2: 85 , and by Bartholomae), but gradually a more sceptical attitude became prevalent: Meillet and Benveniste (1931: 163) call $\theta$ äigraci'd'origine obscure' and Kent (1953: 55) says 'etymology uncertain', although on p. 187 he refers to Justi. The situation has changed since the publication of Eilers' work on the name of the Persian New Year festival (1953). Eilers accepted the major elements of Justi's explanation except with respect to the formation of $\theta$ äigraci-. Developing ideas expressed earlier by Marquart (1905: 126ff.) and Justi (1897: 247), Eilers has shown that several months of the Old Persian calendar are named after the festivals which were held during them: Bāgayädi- (the seventh month) after *bagayāda- '(festival of) the offering to Baga', Áciyaddiya(the ninth month) after * açiyāda- '(festival of) the fire-offering'. ${ }^{15}$ Eilers therefore assumed (p. 43) that $\theta$ äigraci- contains the feminine suffix *-ci-' $\mathrm{zu}$ einem maskulinen Eigenschaftswort auf -ka gehörig' and means 'die mit Knoblauchverbundene (Zeit)'; however, he recognised the problem that the feminine gender is rather unexpected since the Old Persian months seem to be masculine adjectives qualifying the noun mäh- 'month' (Kent 1953: 55).

${ }^{13}$ The Persian garlic festival Sìrsūr, during which people eat meat with garlic in order to keep of the Jinn and send children to school to learn a trade (Steingass s.v.), is held on the 14th of Dadv (Eilers 1953: 42), i.e. in December. Since the time schedule of the festivals may have changed during the centuries, this does not invalidate the connection.

${ }^{14} \mathrm{Cf}$. Wüst 1966: 153ff., who further adduced Skt. Sigru (RV), the name of a people, and, possibly,

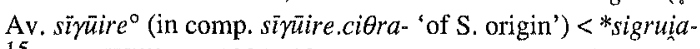

${ }^{15}$ Sims-Williams 1991: 182 recently adduced Sogd. $n^{2} w s r \delta y c$, Choresmian $n^{\prime} w s^{\prime} r c y$ (apud Bīrūnī), which point to *Näwasardačiya- '(month) of the New Year festival (*Nawa-sarda-(ka-))'
The formation of $\theta$ äigraci- was further clarified by Wackernagel (cf. Wackernagel and Debrunner 1954: 303), who saw that Indo-Iranian vrddhi derivatives often substitute $-i$. for $-a$ - in the second member. Among Iranian examples such as Av. mäzdaiiasni- 'belonging to the Mazda-worshippers' to mazdaiiasna-,

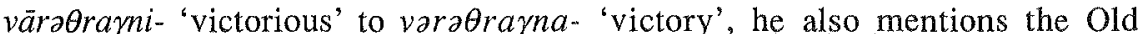
Persian month-names bägayädi-, ädukani- and $\theta$ äigrci- (spelled thus). In other words, $\theta$ äigraci- must be analysed as a vrddhi-formation '(the month) belonging to the $\theta$-festival'. The name of the festival cannot be determined with certainty,

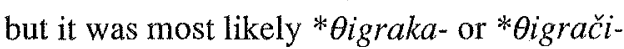

One of the Benennungsmotive for 'garlic' is the arrow-like shape of its shafts. For instance, English garlic, OE gārlëac is actually 'spear-leek' (OE gār 'spear, lance'). It is therefore attractive to assume that Pers. sir and, possibly, OP * $\theta$ igra ${ }^{\circ}$ are related to Ir. *tigra- 'sharp', *tigri- 'arrow', which would mean that these words are borrowed from an Iranian, presumably Scythian, language with the regular development of $* i$ - into $* t^{s} i$-, An additional argument in favour of the Scythian origin of this word is the fact that garlic is native to Central Asia (Encyclopaedia Britannica). It is possible that Skt. śigru- 'Moringa pterygosperma' also belongs here as an Iranian loanword. ${ }^{16}$ Its connection with Rgvedic Sigru-, the name of a people (see n. 14), remains hypothetical, although not impossible.

3.5. I would like to add to the dicussion on OP Aäigraci- a piece of Ossetic evidence, which, to my knowledge, has never been mentioned in this connection. One of the Ossetic spring festivals is cyrriscen/ciryescen, in Iron also called Atynceg (after the Greek saint 'AOnvoүÉvn, cf. Abaev, IESOJ, s.v.). This festival marks the beginning of the mowing season. In the excellent book by Cibirov on the Ossetic agrarian calendar, we find the following description (1976: 193; translation mine): "Nobody among the Ossetians is allowed to start mowing when he chooses, until in July all the inhabitants of a village and district come together for a celebration, called Atynæg. During this festival, the old men after long deliberations decide whether it is time to start mowing. When the day is set, it is announced that whoever takes a scythe in his hands before this date will be responsible for bad weather.' The festival is always held on a Sunday, whereas the actual mowing starts on Monday or Tuesday depending on the local tradition.

${ }^{16}$ In the Encyclopaedia Britannica, we find the following description of moringa pterygosperma: 16 In the Encyclopaedia Britannica, we find the following description of moringa pterygosperma
'The drumstick tree, also called horseradish tree, small, deciduous tree, of the family Moringaceae, native to tropical Asia but also naturalised in Africa and tropical America. Drumstick trees can reach a height of about $9 \mathrm{~m}$ (30 feet); they have corky gray bark, branching, fernlike leaves, and scented clusters of white flowers. The dagger-like fruits sometimes are $45 \mathrm{~cm}$ (18 inches) long. Flowers, pods, leaves, and even twigs are cooked and enten. A horseradish-flavoured conciment is prepared fion its retention of scents.' It seems attractive to suppose that the tree has got its name from the daggerlike (or spear-like) fruits. 
Similar festivals also take place elsewhere in the Caucasus, in Georgia, Abkhazia, Ingushetia etc. ${ }^{17}$

The name of this festival is usually interpreted as a compound meaning literally '[time for] taking up the sharp [things]'; cf. Abaev, IESOJ, s.v. cyr "vremja, kogda berutsja za ostroe" (t. e. za kosy, načalo senokosa)' ("time when people take up the sharp things, i.e. the scythes; the beginning of mowing'). The first part of the compound is cyry/ciry 'sharp, sharp thing', ${ }^{18}$ which is a regular reflex of PIr. *tigra-. The second part is iscen/escen (from PIr. *ayas(a)-+-ana-), a verbal noun to isyn/esun 'to take'. ${ }^{19}$ This transparent analysis has a strong flavour of folk etymology, however. It remains a distinct possibility that the original meaning of the festival was 'collecting garlic'. When the Ossetians took to using a different word for 'garlic' (Iron nury from Georgian niori; Digoron boden $<$ PIr. *baudana- 'smelly'), ${ }^{20}$ they no longer understood the name of the ancient festival. As a result of the reinterpretation, cyryiscen/ciryesan has become one of the names of the mowing festival.

This brings us back to Justi's idea that the old name of the festival may have been * Oigrači- 'garlic collector'. Wüst (1966: 151f.) has argued that this interpretation of $\theta$ äigraci- is morphologically impossible, since the root $\mathrm{ci}$ - 'to gather' is anit and all root nouns of this structure have a final $-t$ - in Indo-Iranian. ${ }^{21}$ This argument does not hold if we are dealing with a loanword, however. Scythian may have lost the final $-t$ very early, so that the word was taken over into Old may have lost the final $t$ very eared by $i$ syn/esun the original compound *tigra-čit may have been remade into the virtual *tigraayasana- > cyryisan.

\section{REFERENCES}

Abaev, V. I. (1949), Osetinskij jazyk i fol'klor (Moscow-Leningrad).

- (1958-1989), Istoriko-ètimologičeskij slovar' osetinskogo jazyka, I-IV (Moscow- Leningrad).

17 In Georgia, for instance, June or July is called tibisay 'month of mowing, a grass-month' (cf. Gippert 1986: §3.3).

18 In Modern Ossetic, the word for sharp things in general is cyrrag/ciryag.

19 In Modern Ossetic, the word for sharp things in general is cyrrag/ciryag. ${ }^{19}$ Abaev, IESOJ, s.v. follows Miller's derivation of the verb from PIr. "ais- 'to rule', which is im-

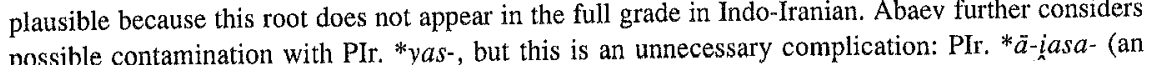
inchoative to $* \tilde{a}$-iam-) can regularly yield Oss. isyn through the stages *aiasa- $>*$ *aiasa- (East Iranian shortening before $D>*^{*}$ ais $V$ - (Oss. syncope, for which see Cheung 2000) $>$ Oss. isyn/esun

20 sering bey Serge Stror s:urge, Lezg. serg, are likely to be borrowed from Alano-Sarmatian *cirgV (and not related to ProtoEast-Caucasian *swVtR, as hesitantly suggested in Nikolaev and Starostin 1994: 972), thus indirectly proving that Oss. cyry originally had the meaning 'garlic'.

${ }^{21}$ Incidentally, Justi himself saw the difficulty, but in his time it was not certain that this rule applied to Iranian as well.
- (1979), 'Skifo-sarmatskie narečija', in Osnovy iranskogo jazykoznanija. Drevneiranskie jazyki, 272-364 (Moscow).

Bailey, H. W. (1943), Zoroastrian problems in the ninth-century books (Oxford). Reprinted with new introduction 1971).

Bartholomae, C. (1904), Altiranisches Wörterbuch (Strassburg).

Bielmeier, R. (1989), 'Sarmatisch, Alanisch, Jassisch und Altossetisch', in R. Schmitt (ed.), Compendium Linguarum Iranicarum, 236-45 (Wiesbaden).

Brandenstein, W. and Mayrhofer, M. (1964), Handbuch des Altpersischen (Wiesbaden).

Cheung, J. (2000), Studies in the historical development of the Ossetic vocalism (PhD. thesis, Leiden).

Cibirov, L. A. (1976), Narodnyj zemledel'českij kalendar' osetin (Cxinvali).

Eilers, W. (1953), Der alte Name des persischen Neujahrsfestes. AAWLM, 1953/2.

EWAia $=$ Mayrhofer 1986-2001.

Frejman, A. A. (1948), 'Plenennyj vrag Darija-skif Skunxa', Izvestija Akademii Nauk

SSSR, Otdelenie literatury i jazyka, 1948: 235-40.

Geldner, K. F. (1951-1957), Der Riguveda, aus dem Sanskrit ins Deutsche übersetzt und mit einem laufenden Kommentar versehen, 4 vols. (Cambridge, Mass.).

Gershevitch, I. (1954), A grammar of Manichean Sogdian (Oxford).

- (1959), The Avestan hymn to Mithra (Cambridge).

$G I P=$ Geiger, W. and Kuhn, E. (ed.) Grundriss der Iranischen Philologie, Strassburg $1895 \mathrm{ff}$.

Gippert, J. (1988), 'Die altgeorgischen Monatsnamen', in F. Thordarson (ed.) Studia Caucasologica I: Proceedings of the Third Caucasian Colloquium Oslo, July 1986, 87154 (Oslo).

Herzfeld, E. (1938), Altpersische Inschriften (Berlin).

Hoffmann, K. (1957), 'Zwei vedische Wortsippen: 1. kavar, 2. drü', MSS, 10, 59-71. (Reprinted in Hoffmann 1976: 411-21.)

- (1958), 'Altiranisch', in Handbuch der Orientalistik, 4: Iranistik, 1: Linguistik, 1-19 (Leiden). (Reprinted in Hoffmann 1975: 58-76.)

- (1975, 1976), Aufsätze zur Indoiranistik, I-II (Wiesbaden).

Hoffmann, K. and Narten, J. (1989), Der Sasanidische Archetypus. Untersuchungen zu Schreibung und Lautgestalt des Avestischen (Wiesbaden).

IESOJ = Abaev 1958-1989.

Justi, F. (1897), 'Die altpersischen Monate', ZDMG, 51: 233-51.

Kuz'mina, E. E. (1994), Otkuda prišli indoarii? Material'naja kul'tura plemen andronovskoj obščnosti i proisxoždenie indoirancev (Moscow)

Lecoq, P. (1987), 'Le mot farnah-et les Scythes', Comptes-rendus de l'Académie des Inscriptions \& Belles-Lettres, 1987: 671-82.

Lubotsky, A. (1998), 'Avestan $x^{v}$ aranah-: the etymology and concept', in W. Meid (ed.) Sprache und Kultur. Akten der X. Fachtagung der Indogermanischen Gesellschaft, Innsbruck, 22.-28. September 1996, 479-88 (Innsbruck).

- (1999), 'Avestan compounds and the RUKI-rule', in H. Eichner and H. C. Luschützky (ed.) Compositiones indogermanicae in memoriam Jochem Schindler, 299-322 (Prague).

Marquart, J. (1905), Untersuchungen zur Geschichte von Eran, II (Leipzig).

Mayrhofer, M. (1986-2001), Etymologisches Wörterbuch des Altindoarischen, I-III. Indogermanische Bibliothek, Zweite Reihe: Wörterbücher (Heidelberg).

Nikolaev, S. L. and Starostin, S. A. (1994), A North Caucasian etymological dictionary (Moscow). 
Schmitt, R. (1990), Epigraphisch-exegetische Noten zu Dareios' Bisutün-Inschriften. Sitzungsberichte der Österreichische Akademie der Wissenschaften, Phil.-hist. K1., 561 (Vienna).

Sims-Williams, N. (1991), 'Mithra the Baga', in Histoire et cultes de l'Asie centrale préislamique, 177-86 (Paris).

Skjærvø, P. O. (1983), 'Farnah-: mot mède en vieux-perse?', Bulletin de la Société de Linguistique de Paris, 78: 241-59.

- (1994), 'Hymnic composition in the Avesta', Die Sprache, 36/2: 199-243.

Vogelsang, W. J. (1992), The rise and organisation of the Achaemenid empire: The Eastern Iranian evidence (Leiden).

Wackernagel, J. and Debrunner, A. (1954), Altindische Grammatik, II,2: Die Nominalsuffixe (Göttingen).

Wüst, W. (1966), Altpersische Studien. Sprach- und Kulturgeschichtliche Beiträge zum Glossar der Achämeniden-Inschriften (Munich). 